\title{
Informed dissent: the view of a disabled woman
}

\author{
Alison Davis Society for the Protection of Unborn Children
}

\section{Author's abstract}

Madeleine Simms begins her article by saying that it will attempt to 'redress the balance' of views on the conflicting rights of handicapped children and their parents. I, on the other hand, will argue that no semblance of a balance has yet been achieved, and that her questions and conclusions merely serve to tip the scales further away from a genuine rights-based theory to a pragmatic utilitarian assessment of individual 'worth'.

My own perspective differs fundamentally from that of Ms Simms in that I believe it to be a scientifically demonstrable fact that each individual life, human by virtue of its genetic code, begins at fertilisation and continues thereafter in an unbroken line through the stages of embryo, fetus, infant, toddler, teenager etc until death, natural or unnatural, intervenes. I do not believe there is any logically significant point other than fertilisation at which life can be said suddenly to commence. That being so, the whole concept of rights, what they mean and how they should be exercised, becomes a matter of crucial importance.

If human rights are to have any meaning, they must apply equally to all human beings. I consider myself to be such a being, with the same consequent responsibilities as everyone else, and the same basic rights. I believe my rights began when I began - at fertilisation - but presumably Ms Simms thinks her own rights began at some unspecified time when she became either a human being, or was already a human being but became a 'person'. The fact that I am severely handicapped due to spina bifida adds a different perspective, and perhaps a greater authority to my arguments, since many babies who would otherwise grow up to be like me are nowadays aborted or 'allowed to die at birth' (such a comfortable euphemism for sedation and starvation) on the grounds that they do not qualify for human rights despite their indisputable humanity.

If Madeleine Simms would accord me equal rights now, including the right to life, it would be interesting

\section{Keywords}

Handicapped infants; rights of handicapped infants; human rights. to know why and when she believes those rights began, since she would claim a right to kill babies solely $\vec{N}$ on the grounds that they are handicapped in exactly the iv same way. If she does consider I have an equal right to life now because I am older, then so too must the severely mentally handicapped young adults who formed the basis of her study. This would mean, of course, that however objectionable or burdensome they or I may now be, no one, including our parents, has the right to kill us. If they attempt to do so, they will be punished, just as they would be if we were not handicapped.

Taking as a definition of 'right' something we can expect others to extend to us as a duty, rights must devolve to each individual equally, and not just according to such extraneous criteria as rationality, desires for the future, or degree of 'worth'. Otherwise $\overrightarrow{\overrightarrow{0}}$ right and power would become synonymous, my power to designate others as irrational or unworthy would justify a right to kill them, and our whole legal system, designed to protect the weakest members of society would then fall. In other words, all human $\bar{\varnothing}$ beings suffer from imperfections, but the fact that we judge some other people to be more imperfect than ourselves does not give us the right to kill them.

Thus, if both handicapped and non-handicapped people have the same right to life today as they shared 0 yesterday and can expect to be accorded tomorrow, we $\square$ must decide when those rights began. In my view there is no room for arbitrary or vague decisions about such matters. If I expect others to respect my rights o throughout my life from beginning to end, and if $I_{0}^{N}$ believe my power to demand and protect my rights $\mathbb{\omega}_{\mathrm{N}}$ should not affect my entitlement to them, I must surelyo extend those same rights to others.

Ms Simms seems to have a very nebulous idea of the $\frac{\text { }}{\mathbb{D}}$ concept of human rights, since she is here asking? parents to decide whether they would have accorded 70 their children the rights they now enjoy from the beginning of their lives, if they had known they would be handicapped. They are also being asked if they would deny these rights to similarly handicappedofuture children. This is most definitely not the same thing as asking if they would have preferred theiro children had not been handicapped, though it sometimes appears that the two are being contused $\frac{\bar{C}}{\zeta}$ 
Naturally all parents wish their children to be as healthy as possible, and of course handicap can cause great unhappiness and difficulty for parents, though that is by no means a certainty. However, unless we believe that power is a right as strong as the right to life, I think we can only conclude from assessing such 'quality of life' factors that some parents of handicapped children suffer serious problems and need help. We cannot conclude from that that the problems are so serious they override the child's right to life, and that they could have been solved if we had killed the affected child at an early enough age.

The idea that such matters can be simply a question of right and wrong is unpopular because it has become fashionable to talk of 'grey areas' and the misery handicap can cause. Nevertheless everyone recognises that the killing of older human beings is unequivocably wrong, so it would seem that once the idea of wanton killing starts to threaten their own rights even utilitarian thinkers such as Ms Simms suddenly recognise a rights-based theory. However, if it actually has no foundation other than as a legal/linguistic fiction designed to accord rights to those currently in power who regard themselves, but not all others, as worthy of life, it is so flimsy as to have no real basis at all.

The problem with granting a right to life only on the basis of predicted future potentialities is that no one can know or accurately predict the quality of life of another. Parents of able-bodied children are not asked to predict their childrens' future potential at birth, neither are they allowed, if they already have one child who is a glue sniffer, or an alcoholic or a drug addict, to abort a subsequent child on the grounds that s/he might turn out the same. Handicapped brothers and sisters are no more likely to be 'the same' than ablebodied ones, though this is something commonly misunderstood by those who consider themselves 'normal'. I am a unique individual, different from everyone else, including others with spina bifida, and although I have often been referred to by doctors as 'a spina bifida' I am no more that than I am 'a headache' or 'a stomach ache' occasionally. You cannot discuss any disease or handicap in isolation from a person who has it.

There seems to be a strange misunderstanding of the role of surgery and medicine for the handicapped newborn, which I think is deliberately perpetrated in order to permit the killing of the ones who are deemed not worth saving. Sedation and starvation to death would be termed murder if the baby were wanted and able-bodied, and subjecting handicapped babies to operations is no more treating them as 'guinea pigs than, for instance, removing a duodenal atresia from an otherwise normal child. Both are standard life-saving treatments, which should be given according to the medical indications, and not according to an arbitrary assessment of 'potential worth'.

Ms Simms seems to regard children, and particularly handicapped children, as in some way the property of their parents, which I believe is wrong. I do not doubt that these parents love their existing handicapped children, and indeed I am not suggesting that parents should be forced to bring up children they cannot cope with, whether or not they are handicapped. Unlike Ms Simms however, I think there is a choice other than killing or unwilling responsibility for the child, though her strong suggestion that handicap 'breaks up families' seems contra-indicated by this study, since only two of the mothers were divorced or separated. An alternative she does not mention, but which does fit a rights-based theory for both parents and child, does exist, since, contrary to popular belief, adoption is a realistic possibility for even severely handicapped children and would appear to be the obvious non-violent solution to the problem. No one is requiring parents to 'sacrifice their lives' either physically or metaphysically, and it is a corruption of both language and truth to suggest they must.

The balance that needs to be redressed is the assumption that we have any right at all to attempt to assess whether another person is worthy of continued existence. In my view any such attempt lays one open not only to the possibility of being rated as unworthy by someone with more power, but to the demolition of the whole concept of individual human rights. Ms Simms's article not only fails to redress the balance, but in tipping the scales further even than the Dr Arthur case towards materialistic utilitarianism, it makes the fall from universal human rights all the more precipitous and ultimately catastrophic.

Alison Davis is the Organiser of the Handicap Division of the Society for the Protection of Unborn Children. She is also a founder member of Disabled Women for Life. 